The Cultural Politics of Introducing Popular Music into China’s Music Education

\title{
The Cultural Politics of Introducing Popular Music into China's Music Education
}

\author{
Wai-Chung Ho and Wing-Wah Law
}

Since embarking on its course of economic reform and opening up to the world in the late 1970s, China has moved from a planned economy to a socialist-market economy; the resultant social and cultural changes have been many, and are reflected in the country's school music curriculum. This paper first introduces the historical background of popular music in the community and in school music in China in the twentieth century. Second, it explores the reform of music education that has, from the turn of the millennium, included popular music in school music education. This is followed by a discussion of the integration of popular music into the school curriculum in terms of how music education and cultural politics are shaped by the social and political relationships between: (i) contemporary cultural and social values and traditional Chinese ideologies; (ii) collectivism and individualism; and (iii) nationalism and globalism. It is argued that, despite the introduction of popular music and the emphasis put on it in some areas of school music education, the Chinese state still uses traditional Chinese culture and values to enhance its legitimacy and consolidate its authority. 
The Cultural Politics of Introducing Popular Music into China's Music Education

\section{Introduction}

In modern urban mass societies, popular culture has developed as a result of industrial mass production and the introduction of new technologies of sound and image broadcasting and recording. Modernization theorists from Karl Marx to Daniel Bell have argued that economic development brings pervasive cultural changes. Music, film, video games, CD-ROMs, digital audio players, digital cable, cell phones, and television dominate the lives of our youth. Some call it the information age; others prefer the terms "technoculture" (Robins and Webster 1-10), or global media culture or globalization, with reference to the dialectical process in which the global and local exist as "combined and mutually implicating principles" (Beck 17). Popular culture changes constantly across place and time. Theories of the role and objectives of popular culture in society show it to be inextricably bound up with rapidly changing cultures (Hall).

In recent years, globalization has come to the fore, resulting in substantial concern and debate on social policy, culture, politics, and communication among the informed public at large (Appadurai Modernity at Large; Bauman; Bhagwati; Castles and Davidson; Giddens; Kiely; Lieber; Singer; Tomlinson). Appadurai ("Disjuncture and Difference"), by focusing on mass migration and electronic mediation within globalization, provides insight into popular consumption patterns. It is also argued that, if we are to understand of the impact of educational policies and developments, we must take into account the cultural experiences of children and youth both in and out of schools (Duncan-Andrade; Fain; Suárez-Orozco and Qin-Hilliard; Valenzuela).

Music is a fundamental component of popular youth culture, preferred over movies and television (White and Mccormack 122). Since Swanwick's Popular Music and the Teacher and Vulliamy and Lee's Pop Music in School, a substantial literature on the educational aspects of 
The Cultural Politics of Introducing Popular Music into China's Music Education

popular music has developed. The 1968 Documentary Report of the Tanglewood Symposium states that "music repertory should be expanded . . . including currently popular teenage music" (Seifried 168). Other literature studies present justifications for popular music as an object of study (Gass; Newsom), and ways of studying and teaching it (Gass; Newsom), and ways of studying and teaching popular music (Dunbar-Hall Teaching Popular Music, "Designing a Teaching Model for Popular Music"; Dunbar-Hall and Wemyss; Lowe; Middleton; Winter). Green (How Popular Musicians Learn, "Popular Music Education") proposes that the ways in which popular musicians learn offer alternative and successful methods for formal music education and the teaching of music in general. She examines how adapting some informal popular music learning practices for classroom use could positively influence pupils' musical experiences and meanings. The practice of popular music has become common in secondary education (Brown; Shah; Winter), and the musicological study of popular music has been established in higher education (Cloonan; Evelein; Lebler; Seifried).

With special reference to China, this paper examines under-researched relationships between social transformation, popular music and education reform. Western and Taiwanese popular music dominated the local music market in China after the implementation of China's open-door policy in 1978, and local popular music in China only began to be developed in the 1980s. The term "popular music" refers here to Western and local music widely popularized in the mass media, including mainstream styles such as rock, rap and soul; Japanese and Korean popular music have also become influential in Chinese society since the 1990s. However, as official music curriculum guidelines do not specify the types of popular music that should be delivered in school education (Ministry of Education, People's Republic of China), the authors 
The Cultural Politics of Introducing Popular Music into China’s Music Education

focus on the social and political meanings of popular music in China's education, and not on what specific types of popular music should be taught and learned in the school curriculum.

The paper begins by challenging contemporary debates on popular music in school education, asking two key questions about the dynamics of developing a culturally relevant curriculum for students in China: (1) how is popular music integrated in school music education?, and (2) what are the challenges to China's incorporation of popular music into the classroom and the larger school culture? It will examine the very different type of challenges that post-socialist China has faced in its attempt to move beyond traditional oppositions between culture and power, tradition and modernity, and global and national forces, by pointing out the vital role that imagination plays in popular music and how music contributes to contemporary education.

\section{An Overview of Popular Music and Education in the Twentieth Century}

China adopted a "closed-door" policy towards the rest of the world for many centuries. From the sixteenth century, Europeans came to China for missionary purposes, viewing the country as "ripe for Christian conversion" (Garrett 149); the first significant mission was launched in 1552 by St. Francis Xavier (1506-1552), a pioneering Roman Catholic priest and missionary and co-founder of the Society of Jesus (the Jesuits). European music was brought to China by such Roman Catholic priests and Protestant missionaries, who were probably the earliest teachers of Western music, in particular choral singing and harmonium playing, in China (Ho, "China” 190-91; Scott 130). Tonic Sol-fa was introduced to China in 1862 through the Hong Kong missionary work of James Legge (a leading sinologist and representative of the London Missionary Society) (Southcott and Lee 214; Stevens 60). In the early twentieth century, Western-style music education was introduced into China with the help of foreign-trained Chinese musicians and music educators and of 
The Cultural Politics of Introducing Popular Music into China’s Music Education

Western musicians (Ho "Westernization and Social Transformations" 292-97). Xiao Yu-mei (1884-1940), known as the "father of modern music education in China", believed that Western music was more advanced than Chinese, and that China should learn from the West to improve its own music and musical instruments (Ho, "Westernization and Social Transformations" 296).

Shanghai was first opened to the West as one of the first "Treaty Ports" created by the Nanking Treaty, which ended the Opium War in 1842. The modernization of Shanghai began in 1843, with the opening of its harbor for the first time to the outside world. Owing to its colonial status, Shanghai soon became an important site for the development of modern and contemporary Chinese music in the nineteenth century.

At the beginning of the $20^{\text {th }}$ century, a young Frenchman called Labansat bought an imported gramophone from a foreign firm called Moutrie and Company, established an outdoor stall on Tibet Road in Shanghai and played gramophone records for passers-by (Jones, Yellow Music 53). He charged his customers 10 cents apiece to listen to a novelty record named "Language Foreigners" (Yangren dixiao); if they were able to restrain their laughter, they would receive a refund. By 1908, Labansat, with help from a French recording engineer and a Chinese assistant from Ningbo (one of the oldest cities located on the northeastern of Zhejiang province in China), set up "Pathé ${ }^{1}$ Orient" (also known as "Pathé Asia”). In 1916, Pathé opened a record factory in Shanghai, during a period when traditional Chinese folk songs and opera still dominated in society (Jones, Yellow Music 61).

The development of Chinese popular music can be traced back to Shanghai and its association with jazz during its romanticized "golden age" in the 1920s and 1930s (Ogawa 144; Field 1-18; Jones, Yellow Music 1-20). At that time, Chinese popular songs were called shidaiqu (meaning music for the time), and included jazz, Hollywood film songs, and popular Chinese 
The Cultural Politics of Introducing Popular Music into China's Music Education

urban ballads performed in the entertainment quarters (Wong 71). The modern Chinese popular music created in Shanghai gained popularity in the nightclubs and dance halls of other major Chinese cities in the 1920s. Nonetheless, the balls hosted in Shanghai by Westerns both mirrored and reproduced "the political culture of Euro-American nationalism and imperialism", as a representation of "cultural and racial superiority over China" and other colonial cities in Asia (Field 25).

Li Jinhui (1891-1967), a songwriter and composer from Hunan province, was a pioneering advocate of writing songs for children, and is regarded as "founder" of Chinese popular songs (Huang 46). His works show Western jazz influences from American jazz trumpet player Buck Clayton ${ }^{2}$ (1911-1991), who worked closely with Li for two years. After the fall of the Qing dynasty (1664-1911), Li was most notable for creating a new musical form for Chinese popular music that moved away from established musical forms. Despite featuring elements of Western musical style, Li's popular songs were "basically traditional tunes accompanied by western musical instruments" (Huang 46). His compositions were a combination of the musical characteristics of Chinese folk music and big band jazz.

From 1916 to 1926, as a Chinese language and music educator, Li wrote Mandarin textbooks about effective classroom instruction, and songs and short musical dramas for his students to learn and perform (Jones, Yellow Music 81). In his written works, he strove for school education that would promote "literature in the national language... ethical citizenship, knowledge of nature, painting, handicrafts, music and sports" (qtd. in Jones, Yellow Music 170). In 1923, he published the first of his eleven children's musicals (S. W. Chen 110), and broke with Chinese tradition by allowing young girls, including his own daughter, Li Minghui, to sing and dance on stage (Jones, Yellow Music 86-90). In 1927 Li organized the "Chinese Dance 
The Cultural Politics of Introducing Popular Music into China's Music Education

School" and the "Chinese Song and Dance Troupe". In 1929 he found the "Bright Moonlight Song and Dance Troupe", which toured the country and had a great influence on the development of Chinese popular songs. In addition to children's songs and theme songs for Chinese sound films, Li also wrote a large number of love songs, adopting various styles drawing on "jazz, Hollywood film music or Chinese pentatonic scales", with lyrics from "classical Chinese love poems or romantic clichés of Tin Pan Alley" (S. W. Chen 110).

Protest songs were also widely promoted by Chinese musicians between the late 1920s and the mid 1940s. After the Japanese occupation of Manchuria in September, 1931 and the bombing of Shanghai in early 1932, many musicians, writers, intellectuals and filmmakers focused their work on the fate of their country, and patriotism in music was highly valued (Steen 124). In the 1930s and 1940s, significant Chinese composers like Nie Er (1912-35), Xin Xinghai (1905-45) and Zhao Yuanren (1892-1982) made use of tunes in the national style to make contributions to the new Chinese music. Historians explain the songs composed by Chinese musicians as the key to the popularity of the leftist films of the 1930s and 1940s (Yeh 88-93). Zhou Xuan's (1920-1957) 1937 movie theme song “When Will You Return”? (Heri Jun Zailai) captured the mood of wartime China, while Nie Er's "March of the Volunteers", originally the theme song for the 1935 patriotic movie Children of the Storm (Fengyun Ernu) was very popular during the war years, and was later adopted as the national anthem of the People's Republic of China (PRC) (Ho, "Social Change and Nationalism" 440-41).

The development of nationalism in music education was further strengthened by the military activities during the 1930s and 1940s, particularly the eight-year war against Japan (1937-45). Anti-war and patriotic songs with Western diatonic melodies were adopted as teaching materials (Ho, "Westernization and Social Transformation" 298; Kwok 32). China's 
The Cultural Politics of Introducing Popular Music into China’s Music Education

Ministry of Education set music education syllabi for primary and secondary schools, wrote both Chinese and English versions of "Collections of Anti-War Songs" and trained students to sing the "Choral Work for Thousands of People". Consequently, singing anti-war songs became significant musical activities from 1937-1945.

Besides anti-war protest songs, Chinese Communist Party (CCP) propaganda songs were also featured prominently in the popular culture. The CCP adopted songs as a propaganda vehicle to fight against their two enemies, "the Japanese and the Guomingdang-and, more important, to reshape people's mind" (Hung 904). This practice began to develop into a coherent theoretical concept of using folk art for propaganda purposes in Communist-controlled Yan'an ${ }^{4}$. During a lecture to open the Yan'an Party School on 1 February, 1942, Mao declared that "it is a fact that the Party's General Line is correct and unquestionable" (Spence 99). In another famous speech, delivered at the Yan'an Forum, emphasized the nature of art in class society; music and other arts, Mao asserted, were governed by Marxist-Leninist-Maoist ideology and were required to serve the workers, peasants, and soldiers, as well as convey the messages of the government in communist China (Hung 907; Perris 6). The Yan'an Forum dictated the official style in art and literature in China that persisted from the establishment of the PRC in 1949 until after the death of Mao in 1976. Typical of that style, one Yan'an song," Our Leader Mao Zedong”, composed by a rural labor hero named Sun Wanfu, expresses the boundless love of the revolutionary people for Mao Zedong. Its lyrics said (Hung 918-19):

Sun, moon, stars shine up above,

Food crops and myriad things thrive below,

Here comes our Chairman Mao,

Here comes our Chairman Mao. 
Who uproots poverty

And gives us a new life.

Other propaganda songs carried similar messages about Mao's role as a unifying symbol and the source of hope for the new China.

Following the founding of the PRC, on 1 October 1949, the composition and development of music education were required to conform to Marxist-Leninist-Maoist ideology in order to convey the political and revolutionary messages of the Chinese government. Education became an instrument for the transmission of the new beliefs and values required to build a socialist revolutionary society. The songbooks for school children introduced under the CCP reflected a strong revolutionary orientation, and served as political propaganda to depict the new China's enemies (Cathcart 209). The CCP attacked American "cultural imperialism" and "the alleged toxicity of Western music via propaganda cartoons that juxtaposed ugly, drunken, and lecherous Americans with jazz and dance halls" (Cathcart 205). Barely six months after the establishment of the PRC (on 6 April, 1950), the People's Daily, the organ of the Central Committee of the CCP, published the lyrics to a "teacher's song”, which highlighted teachers' role as cultural militants (qtd. in Cathcart 207):

We are China's teachers,

Soldiers teaching China's new youth,

We are Chairman Mao’s cultural soldiers,

Bringing the country forward to a new dawn.

Another school song, entitled "Moonlight on the Nine-Dragon Mountain", denotes how the Party placed "the onus of past anti-Japanese experience onto new generations of Chinese youth" (Cathcart 
The Cultural Politics of Introducing Popular Music into China's Music Education

209). Song texts about the Korean War, distributed by Chinese authorities in 1950, exemplify "the role of wolf and devil imagery in anti-American song propaganda" (Cathcart 203).

The Cultural Revolution was officially launched on 8 August, 1966. Education and music were major concerns of the revolution. Traditional Chinese music and Western music were both banned for carrying feudal and bourgeois messages, respectively, and Chinese composers and musicians were prohibited from researching either. Popular music was depicted as an inferior cultural form tainted by Western capitalist values and those Chinese who listened to American music or loved American commodities were deemed immoral. The musical repertoire during the Cultural Revolution was restricted to a very few songs, all of which were intended to increase popular enthusiasm for revolutionary ideology. Songs such as "We Have to be Lei Feng ${ }^{5}$-style Good Teenagers" and "Lei Feng: Our Friend in the War" were amongst the common materials learnt by students in school (Ho, "China" 196). The only extra-curricular musical activities that schools were allowed to offer were eight revolutionary musicals: including the symphonic suite "Shachiapang", two ballets ("The Red Detachment of Women" and "The White-haired Girl"), and five operas ("Red Lantern's Record", "Capturing the Tiger Mountain by Strategy", "On the Docks", "Raid on the White Tiger Regiment", and "Shajiabang") (Ho, "China" 196). Besides schools, these revolutionary operas, revolutionary ballets and symphonic works were also performed in "factories and on the fields" (Mittler, "Eight Stage Works" 378). New Songs of the Battlefield, a five-volume anthology of songs published from 1972 to 1976, was intended to cultivate "political campaigns and ideologies" (Bryant 87). Music education was regarded as a political commodity and was monitored to ensure that it conformed to the state's political ideology. Despite their intentions, however, Chinese leaders propagated a revolutionary musical style that was highly Western in its technique, instrumentation and harmonic structure (Kraus 128). 
The Cultural Politics of Introducing Popular Music into China's Music Education

The economic and social reforms resulting from the 1978 introduction of the "Open-door Policy" by Deng Xiaoping (1904-1997) encouraged the establishment of private enterprise, foreign trade and investment, as well as exchanges with foreign cultures, all of which were expected to benefit China's national reformation. The cultural impact of the open-door policy exceeded anything the Chinese state had expected (Hsü 872). The availability of modern electrical appliances, such as radios, cassette players and television sets, led to the rise of popular music in China. China became more exposed to elements of other cultures, including popular music from Hong Kong and Taiwan. In the formation of Chinese popular music in the 1980s, as observed by Brace, there is a chronological progression that begins with pop music produced in Hong Kong and Taiwan (Gangtaiyue), proceeds to music influenced by Northwest folk songs (Xibeifeng) and culminates with mainland Chinese rock (Yaogun Yinyue) and its first popular idol, Cui $\operatorname{Jian}^{7}$ (49-50, also see De Kloet, "Popular Music and Youth in Urban China" 611-612, "Sonic Sturdiness" 323-324). However, a site of symbolic struggle exists in the political arena between China's government and the producers, composers, performers, and audiences of Chinese rock over musical styles and lyrics (Lee, “The East Is Red” 134, Troubadours 161-65). Since the mid-1980s, Chinese rock music has become a central agent of popular resistance against the political systems of the PRC, acting as what some have called the "manifestation of a conflict between feudalism and modernity" (Jones, "The Politics of Popular Music" 154). The dispute between Chinese pop musician Cui Jian (whose lyrics are "often interpreted as politically oppositional) and the PRC authorities, is emblematic of "the ambivalence of government cultural policy" (Lully 135; Schell 318). Cui's song "Nothing to My Name" (Yi Wu Suo You), for example, is, on its surface, a monologue by a spurned lover; Chong, however, notes that, in classical Chinese poetry, a rejected lover's complaint often represents the "grief of the official wronged by the ruler" (20), while Matusitz maintains that 
The Cultural Politics of Introducing Popular Music into China's Music Education

the song "not only [symbolizes] China's rebellious youth", but also delineates "the birth of postmodernism in Chinese pop music" (156). We argue that Cui Jian, whose songs occasionally use such traditional Chinese instruments, as the suona (a reed instrument), the dizi (a transverse flute made of bamboo), and the guzheng (a zither) makes use of the acoustic effects of Western and Chinese musical instruments to shape the political contradictions between the Communist politics and the Open-door Policy (Brace 52). Other Chinese rock bands have established their own style, combining Western rock and Chinese national styles. For example, He Yong's "Requiem March" ends with a Buddhist chant recited by a monk. The heavy metal band, Xin Qiji, sets a Sung dynasty song lyric (ci) "to wailing electric guitars". Lao Wu, lead guitarist for the rock band Tang Dynasty ${ }^{5}$, describes the use of traditional Chinese instruments and images in relation to "cultural essentialism" (Jones, "The Politics of Popular Music" 159).

Foreign record companies began to interact with the Chinese economy in the 1990s, signing some of the mainland's most influential singers to recording contracts - for instance $\mathrm{Na}$ Ying $^{8}$ with EMI and Liu Huan ${ }^{9}$ with Sony. The number of annual Chinese rock album releases increased from just a few in the early 1990s to approximately 40 at the end of the 1990s; the number of small record label also continues to grow (De Kloet, "Popular Music and Youth in Urban China" 615). According to a 1997 survey of 650 Beijing youths between 15 and 25 years of age, their preferred musical genres were pop and rock (De Kloet, "Popular Music and Youth in Urban China" 614); those respondents who preferred rock were found to have a greater involvement in listening to music each day.

In order to enable China to compete in the global economy, China, from the late 1970s to 2000 , enacted several major education reforms and over 200 regulatory changes to promote good educational practice, enhance and universalize primary and junior secondary (i.e. grades $1-9$ ) 
The Cultural Politics of Introducing Popular Music into China's Music Education

school education, increase the number of schools and qualified teachers, and reform education. In 1986 Central China Television (CCTV) broadcasted a program on teaching methods for primary school students and lauded the social value of school music education (Cao 312-4). However, until the implementation of China's most recent curriculum reform, at the beginning of the twenty-first century, neither Chinese nor Western popular music was included in textbook materials, only popular political and revolutionary songs. The political campaigns launched by the CCP in 1981, 1983, 1987 and 1989 to eradicate foreign "spiritual pollution" could be interpreted as attempts to prevent the introduction of popular music into school curricula. For a long time, popular culture was prohibited in China's school music education for fear of spiritual pollution by Western culture, against which China maintained a strong revolutionary orientation (Ho and Law, "Values, Music and Education" 159).

\section{Popular Music Introduced in School Education in the Global Age}

Over the last two decades, the impact of globalization on China's economic growth has been farreaching. About $60 \%$ of China's exports are now produced by foreign investment enterprises (Chow 272), whilst China has become a large and important market for foreign manufacturers (Chow 273). Economic globalization has allowed China's burgeoning economy to affect world economic growth by enabling it to contribute "more inventions, investment, and importation" (Yan 38). Technology has facilitated, even encouraged, this phenomenon. For example, Chinese teenagers account $51.8 \%$ of all Internet users, with more than 175 million users as of 30 July, 2009 (Chinese Internet Network Information Center 17). Chinese mobile phone users are far 
more likely to use their mobiles as MP3 players than are their counterparts in the West (Telecom Asia Staff) - according to a survey of 8,000 people aged 18 and older in 13 counties including China, conducted by Synovate in December, 2009, 16\% had used their mobile phones to watch music videos in the previous month, with the three highest rates being found in India (38\%), Philippines (23\%) and China (20\%).

Chinese culture has been transformed, and the interplay between social reality and the proliferation of digital TV channels makes the study of Chinese popular culture both fascinating and surprising. Chinese TV programmers have joined forces with advertisers to establish "a committed "brand community", encouraging fans to give their "entire support to their favorite idols and their fan community", thus creating a "fan economy" (Jian and Liu 536). An idol, always depicted as an object of worship, is typical someone whose achievements, status, talent and physical appearances are specially appreciated, attracted and recognized by his/her fans, who are referred to as "loyals" in terms of marketing theory (Jian and Liu 536). According to Jenkins, "brand loyalty is the holy grail of affective economics" (72), and the adoration of idols is increasingly prevalent among China's younger generation, who have increasing exposure to pop stars from the West, Hong Kong, Japan, Korea and Taiwan. According to He's survey (90) of 353 junior middle school students, 412 senior middle school students (including vocational senior middle schools or vocational secondary technical schools) and 210 college and university students, the junior middle and vocational senior middle school students were most likely to have idols whom they adored (see Table 1).

(Insert Table 1 about here) 
The Cultural Politics of Introducing Popular Music into China's Music Education

The most preferred idols among students were pop singers, film and TV stars, sports stars and political and military figures (He 88). Among male respondents, the three top-ranking idols were Jay $\mathrm{Chou}^{10}$ (also called Zhou Jielun, a Taiwanese popular icon), Mao Zedong and Zhou Enlai, respectively; among females, the top three were their own father, Zhou Enlai and Jay Chou (He 97). In 2008, the Shanghai Institute of Visual Arts of Fudan University invited Jay Chou to be a performing arts guide, at which time he promised to work as a volunteer to tutor its students and offer them practice facilities when he traveled to Shanghai. Jay Chou's role in music education activities indicates that he is acceptable to the central authorities as an implement.

Western popular culture, especially popular English-language music, has found many ardent fans among Chinese youngsters. According to Rupke's April, 2004, survey of 153 Chinese college students at the Anhui Institute of Education in Hefei, the three most preferred Western songs were My Heart Will Go On by Celine Dion, Country Road by John Denver, and Yesterday Once More by The Carpenters (Rupke and Blank 135; see Figure 1). Most of the students reported that they started to listen to Western music during their high school education (Rupke and Blank 133).

(Insert Figure 1 about here)

High school students in China are expected to learn how diverse types of music and/or song lyrics featured in Western films set a tone or mood to advance the plot and/or express the movies' themes in a manner that elevates the storyline or the moving image as an art form (for example, see Shanghai Music Publisher for Grade 13 (first term) 34-50; Shanghai Music Publisher for Grade 13 (second term) 66-73). Animated films by US producers, including Shrek, Mulan, The Lion King and Finding Nemo are blockbusters in China (International Market News). 
In Finding Nemo, a computer-animated film produced by Pixar Animation Studios for Walt Disney Pictures in 2003, students are expected to understand how sounds and rhythm are used to build emotions in the film, how they foreshadow changes in mood, and how they distinguish the characters (Shanghai Music Publisher for grade 12 (first term) 51-69).

Japanese cartoons became popular in China when CCTV screened a dubbed anime classic Astro Boy ${ }^{11}$, the US version of the Japanese animated series Tetsuwan Atomus (literally Iron-arm Atom), for the New Year in 1981. Since then, foreign cartoons have flooded into China. Chinese fans of Japanese popular culture are called the "Ha Ri Zu" - "Japanese fans". Beijing Comics and King of Comics, the two most popular comic magazines in China, are greatly influenced by the Japanese ( $\mathrm{Ng}$ 2). A teacher at a Shanghai secondary school said that it is common to find primary and secondary school students imitating the style of Japanese and South Korean cartoons in their drawings (Beijing Review). An arts education textbook for senior high school students includes the story and music of Spirited Away, a 2001 Japanese animated film written and directed by Hayao Miyazaki that describes the adventures of a 10-year-old girl in a world of spirits and monsters (Shanghai Music Publisher for Grade 12 (first term) 44-54).

The effects of globalization have also inspired a South Korean-Western cultural hybridity in China in response to the global culture of consumption. In particular, the expression "Korean wave" ("Han Rue" in Chinese or named in "Hallyu") refers to the popularity of Korean TV dramas, movies, popular music, fashion, food, and celebrities on the mainland (see Kim 737-40; Maliangkay 35-7; Pease 176-7). Since the late 1990s, there has been a "significant number of Chinese cover versions of Korean songs recorded"; and "Korean entertainment media files" are exchanged and traded illegally on an enormous scale (Maliangkay 37-8). The Korean boy band H.O.T. made their presence known even before the rise in popularity of Korean TV dramas and 
The Cultural Politics of Introducing Popular Music into China's Music Education

movies in the late 1990s; many Chinese youths aged between 17 and 20 were big fans of H.O.T.'s music and dance, and their popularity immediately led to the development of "South Korean Pop Funs" (Xiong and Li 20). Other Korean singers, such as BoA, CLON, Girls Generation (SNSD), Jang Nara, NRG, and Rain have gained popularity among Chinese youth, and have performed concerts in China. Thousands of Chinese fans lined up outside the Shanghai World Expo on the morning of May 30, 2010 to get tickets to a Korean pop concert featuring Super Junior, BoA and Kangta at the Expo Center that evening.

As China becomes more open, popular music becomes more popular in both society and education. The renewal of music practices and materials in school music education has come about because of rapid changes in Chinese society. The privately owned Beijing Midi School of Music, established in 1993, emphasizes modern musical genres and offers numerous courses on pop and rock performance (Micic 11). Since then, state-owned conservatories have also started to offer modern music education, promote the business of popular music, and train popular musicians. For example, the Popular Music Department of the Shenyang Conservatory of Music in northeast China's Liaoning Province started its pop, jazz, and karaoke singing teaching programs in the mid 1990s (Micic 11). The Sichuan Conservatory of Music established its Pop Music School in 2001 to meet market demands and provide a good foundation for popular music as a discipline; its first four-year undergraduate program features pop singing as a specialty (Pop Music Conservatory of Sichuan Conservatory of Music). Organized by the Pop Music School of the Sichuan Conservatory of Music and Chengtian Digital Entertainment and Technology Corporation and sponsored by the Sichuan Conservatory of Music, the Pop Music Education Forum for Chinese Arts Institutes and Academy Cup for Pop Music Competition were firstly held from 8 November to 11 November 2007. These attempt to establish a new "academic-style" 
The Cultural Politics of Introducing Popular Music into China's Music Education

competition system, renew "existing appraisal criteria and aesthetic values in pop music singing competitions", and align Chinese and international practice (Pop Music Conservatory, Sichuan Conservatory of Music).

Though popular music is not highlighted in the current music curriculum, China's Ministry of Education encourages music teachers to exercise sensitivity and openness in curriculum content, resources and teaching strategies with regard to various musical styles from China and elsewhere (4). Today, scholarship in school music education is expanding due to the emphasis placed on popular music and the manner in which it is taught and learned (Y. R. Chen 63-65; Y.Z. Jin 52-53; W. H. Wu 154-156 and 168; Yang 167). Song materials are adopted current issues to arouse students' interest in classroom singing; for instance, "Going towards Olympia", the first part of a grade-7 music textbook, builds on students' interest in the recent Beijing Olympic games to introduce three related songs (Guo 300-301). According to Guo's survey of 184 music teachers (116 full-time and 28 part-time teachers), and 163 school heads and music education researchers (116 head masters and 47 researchers) in 296 primary and secondary schools, $63 \%$ of the former and $61 \%$ of the latter supported the introduction of popular music in the school curriculum (16).

The immensely powerful influence of popular music on China's youth has led scholars and music educators to consider how best to integrate popular music into the school curriculum. According to Ho and Law's survey ("Challenges to Globalisation, Localisation, and Sinophilia" 227), the musical styles that Shanghai students preferred to be taught in class were Hong Kong, Western and popular music from mainland China (in that order); as a result, alternative methods of music education were developed (Y.Z. Jin 52-53; Lu 117-120; Yang 167), involving a greater diversity of teaching methods and of ways in which music educators conceptualize the study of 
The Cultural Politics of Introducing Popular Music into China's Music Education

popular music in schools (Ho "Dynamics of Social Change"). General music education programs increasingly seek to expose students to a broader range of musical experiences; popular music lends itself to providing students with opportunities to listen, perform, and compose in Chinese music education.

\section{Dynamics of Introducing Popular Music into the School Curriculum}

China's transition from a planned economy to a socialist market economy has changed many aspects of social and cultural life, and posed new challenges for education development in the twenty-first century. The political transition from the post-Mao era to the post-Deng era has continued, with both the so-called third generation of post-Deng leaders, headed by Jiang Zemin (1926 - ) from 1989 to 2002, and the fourth generation leadership of Hu Jintao (1942 - ) since 2003, have gradually shifted their focus on ideological and cultural arenas. Speaking to a joint session of the Australian Parliament, on 24 October, 2003, Chinese President Hu Jintao stressed China's cultural openness, saying that "Chinese culture belongs not only to the Chinese but also to the whole world ... We stand ready to step up cultural exchanges with the rest of the world in a joint promotion of cultural prosperity" (qtd. in Gill and Huang 19). The Chinese government has shown its willingness to open its borders, as demonstrated by the nation's entry into the World Trade Organization (WTO) in 2001, the 2008 Beijing Olympics, and the 2010 Shanghai World Expo. Moreover, President Hu has instructed the nation's leading officials and Party cadres to make "building a harmonious society" a priority for leading China into the twenty-first century. Hu's era is regarded not only as a significant milestone "in the process of transformation from a regional power to a global power", but also in the reconstruction of China's national identity (qtd. in Gill and Huang 19). 
The Cultural Politics of Introducing Popular Music into China's Music Education

The opening ceremony of the 2008 Olympics Games in Beijing was not only a global sports gathering, but also a global cultural gala in which China made cultural exchanges with the rest of the world. Practicing the tenets of cultural harmony and artistic sharing, the Beijing Olympic Committee organized a series of cultural events that included more than 300 performances and exhibitions from some 80 countries and regions. To the thunderous beat of Xia dynasty drums, 2,008 voices welcomed more than 90,000 spectators from all over the world (2070-1600 BC) to the Olympic opening ceremonies. In addition to the usual Olympic slogan (One World, One Dream), the opening ceremony highlighted a Confucian saying - "How Happy We Are, To Meet Friends from Afar!" Chinese singer Liu Huan and British singer Sarah Brightman jointly performed "You and Me", the theme song for the Olympic Games, which was composed by a Shanghai-born French Chinese Chen Qigang. The theme song, which was performed in Chinese and English, symbolizes unity and friendship between peoples, and was the result of a year-long competition that attracted singers and musicians from China, Hong Kong, Taiwan and around the world.

In preparing students for the challenges of an increasingly interconnected and interdependent world, educational reforms in China have had to address both global and national needs. The process of translating global imperatives for music education is always intertwined with social changes and educational reforms that are, in turn, both facilitated and constrained by national conditions and considerations. One very challenging aspect of contemporary music education relates to the part "the school plays in that reproduction" (Green 165). Indeed, music education in mainland China represents a complex interplay between political ideologies and economic globalization. With particular reference to school music education, the purpose of this section is to probe the intersection of popular music, education and cultural politics. This section 
The Cultural Politics of Introducing Popular Music into China's Music Education

will analyze three pairs of social and political relationships that shape music education and cultural identity in the school curriculum in China - the relationship between: (i) contemporary cultural and social values and traditional Chinese ideologies; (ii) collectivism and individualism; and (iii) nationalism and globalism. This section argues that music instruction in Chinese education is used as a tool for shaping the behaviors and ideals of young Chinese through the values and nationalistic messages conveyed through popular songs.

A key issue for China has been how to adapt its revolutionary Communist legacy to the pressures of increasing cultural and economic globalization. Even though the Cultural Revolution greatly disordered Chinese spiritual life, the country was still "held together by the unshakable strength of Chinese culture" (Ding and Saunders 12). There has been a revival of Confucianism ${ }^{12}$ in Chinese society and education since the launch of the project for "education in Chinese traditional virtues" in the 1980s (T. Yu 113) and, despite the pressures of globalization, by and large Confucianism continues to dominate the content of traditional Chinese education. The keynote of Confucian ethics is ren, variously translated as "benevolence", "love", "goodness, "humanity" and "human heartedness". According to Confucian precepts, the dissemination of traditional culture must pay attention to moral education, promote honesty, humanity, loyalty, righteousness and self-discipline, and encourage young people to accept the Chinese media's culture of moral education. The Confucian concepts of filial obedience and communal solidarity are identified as good traditional Chinese virtues in the Implementation Outline on Ethic Building for Citizens, the revised students' conduct code, and in textbooks (Law 604 and 610-13; Lee and Ho 423-24; F. Y. Wang 435).

Popular music is a dynamic cultural force. The Chinese government holds that music can change people's thoughts, morals, qualities, and personalities; not only does it nurture a healthy 
The Cultural Politics of Introducing Popular Music into China's Music Education

artistic interest, it also raises one's whole-person quality (Arts Faculty Teaching Materials Editing Group of the Beijing Physical Education University 2; also see Tian and Du 60-2; Z. X. Wu 60-2). Through singing familial and love songs, such as "Little Black Bird Loves Mama" (People's Music Publisher for Grade 2 (second term) 52-3), "We Have to Protect Our Forest" and "Love to Go Home" (People's Music Publisher for Grade 1 (second term) 66), and "Singing My Beautiful Home" (People's Music Publisher for Grade 8 (second term) 13), children are taught to maintain strong family bonds and to build a harmonious family. Jay Chou's song "Listen to Mummy", which was included in a collection of songs approved for the patriotic education curriculum in Shanghai’s secondary schools (Nyíri 21), includes the lyrics: “...

Listen to mother's words, don't let her get hurt. You want to grow up quickly so that you can take care of her ... Mother gave you the sweater and you should keep it safe, ... so that I still have it on Mother's Day ..." (translated by the authors).

Music has an important place in Confucius's teachings (Xu 124). The purpose of music education throughout Chinese history has been to promote social harmony (Ho "Moral Education" 80-1). Songs found in textbooks praise friendship and commitment to unity, including "We Are Together" (Shaonian Ertong Chubian She for Grade 7 (second term) 13), "We Are Holding Out Our Hands" (People's Music Publisher for Grade 3 (second term) 48-9) and "We Are Good Friends" (People's Music Publisher for Grade 1 (second term) 15), to name but three. Students are taught that love and friendship are a life-long willing involvement in world unity. Despite coming from all walks of life and different cultures, the crucial need facing humanity is to find a unifying vision of the nature and purpose of life in society. The lyrics of these songs focus on the theme of friendship, and may be adopted from Mandarin and English pop songs. The English pop songs "Hand in Hand" by Giovanni Giorgio Moroder (the official 
song of the 1988 Seoul Olympics) and "You've Got a Friend" by Carole King are also prescribed in music teaching (Lin 171).

Second, for a long time popular culture was prohibited in China's school music education, to prevent the spread of Western culture, against which the PRC maintained a strong revolutionary orientation (Ho and Law "Values, Music and Education in China" 152-54; Law and Ho 504-5). Students were denied the opportunity to learn popular music, which was seen as "spiritual pollution", and therefore dangerous to Chinese communism. The term "socialist spiritual civilization" (shehui zhuyi jingshen wenming) is commonly used in the PRC; a example of socialist spiritual civilization can be seen in the 1996 "amazing" series of propaganda posters - including China Is Amazing, Chinese Are Amazing, China's Reform and Opening Up Are Amazing and I Want to Be An Amazing Chinese - led to the production of materials for use in primary and middle schools (Landsberger 559-562).

In 1998, educational propaganda posters themed on loving classmates, teachers and the collective, and on loving and protecting the environment were published, reflecting the model behavior outlined in the CCP Propaganda Department's publication, The Four Loves. School posters titled Loving the Nation usually involve visual images of the national flag of the PRC and/or the constitutions, and promote "unity and friendship within the multiethnic composition of the population" among students in and out of the classroom (Landsberger 563).

Consequently, music education in China has long been a very convenient means of propagating spiritual education. The China state strongly supports the transmission of official popular songs, such as "The Great Wall Is Long", "I Belong to China", and "Today is Your Birthday, China", all of which promote unity, nationalism and other official ideological values (Baranovitch 204). On 1 October 2009, the National Day Evening Gala in Tiananmen Square 
The Cultural Politics of Introducing Popular Music into China's Music Education

warmed up when some 60,000 people began dancing to the popular song "I Love China", and a series of official patriotic songs were performed to celebrate China's $60^{\text {th }}$ National Day. According to Fairbrother's study of one Chinese secondary school, several activities, including music education, were "designed to help students understand China's history and install in them either a sense of pride or shame" (167). For example, an inter-class singing contest for revolutionary and patriotic songs was introduced to help students remember a student movement in the 1920s, and to understand popular desires during the revolutionary period to cultivate a better future for China. The central state welcomes popular songs with revolutionary ideas, making clear its goal is to educate the people in communist ideology. The propaganda productions of the Cultural Revolution (1966-76) were remade and reproduced using new formats, such as DVDs and karaoke. Rock and pop versions of revolutionary songs praising Mao have appeared, as well as "trendy T-shirts, watches, ping-pong racquets, mousepads and porcelain" (Mittler 467).

However, the gradual shift from collectivism to individualism that has emerged since the opening-up of China in 1979 "has brought about more changes in cultural dimensions" (Cao 43). As argued by Cheung and Pan, the abandonment of "radial collectivism" and the rise of "regulated individualism" are responses to "the new socialist era in China" (38). They also claim that Chinese authorities expect the exercise of individuals' autonomy will not "challenge the social and ideological basis of the collective" (47). The newly-established China College English Curriculum Requirements focus on the significance of "the development of individualized study methods and the autonomous learning ability on the part of students. The new model should enable students to select materials suited to the individual needs" (Cao 46). 
The Cultural Politics of Introducing Popular Music into China's Music Education

Patriotic or revolutionary songs have also stimulated heated national debate over the extent to which school music education can encourage collectivism and individualism (Law and Ho 509-10). Whilst individualism implies personal independence, collectivism places greater emphasis on interdependence. By examining Chinese children's decision-making in family, peer and school contexts, Helig et al. (783) find that some Western values, such as personal individual autonomy, are salient areas of their social reasoning and practice. The Chinese state intends to support both collectivism and individualism as delivered in the school curriculum through an emphasis on students' future, as delineated in song lyrics. Individualism is a major factor in China's economic growth. Current textbook materials highlight song lyrics that stress the importance of individualism for China's dynamic society. Titles such as "My Blessed Life" (People's Music Publisher for Grade 1 (second term) 44-9) and My Ideal (People's Music Publisher for Grade 4 (second term) 46-51) are recommended for listening, composing and performing activities. At the same time, teachers are also encouraged to teach songs such as "We Are Marching to a New Era and Great China", which reflect China's changing society and its modernization (Fan 523).

Despite ongoing political differences between the PRC and Taiwan, China's textbooks now include the Taiwanese pop songs "Tomorrow Will Be Better" by Luo Tai-you (Shaonian Ertong Chubian She for Grade 7 (second term) 15), and "Real Hero" by Jonathan Lee (Shaonian Ertong Chubian She for Grade 7 (first term) 15). In March 2005, the controversial song "The Snail”, by popular Taiwanese singer Jay Chou, was selected as a patriotic song by the Shanghai Education Commission. Its lyrics encourage young people to pursue their own success in difficult times (Ho, "Popular Culture" 353, "Dynamics of Social Change"; Shaonian Ertong Chubian She for Grade 7 (first term) 14). Jay Han, a Chinese music critic, says "The Snail" is patriotic in a wider 
The Cultural Politics of Introducing Popular Music into China's Music Education

sense, as it encourages students to achieve personal success and contribute to the overall development of Chinese society (Zou). On the first day of the Chinese national college entrance examination (gaokao) in June, 2009, Beijing students were required to write at least 800 characters expressing their views on a Taiwanese popular song, "I Have a Pair of Invisible Wings", sung by Angela Chang (a Taiwanese pop singer and actress). Its words "invisible wings, flying toward the distance" are thought to stimulate students' imagination. The controlled introduction of popular music attempts to regulate individualism, and to understand how prosocialist China copes with the tension between personal autonomy and socialist collectivism. This cautious approach exemplifies the balance between individualism and collectivism in school music education. The inclusion of healthy Taiwanese pop lyrics is an attempt to join the broader social role of the individual and China's reform agenda. The Taiwanese popular singers and writers introduced in the music curriculum are politically acceptable to the Chinese authorities, inasmuch as they have not declared their political support for Taiwan's political independence ${ }^{13}$, or become involved in the controversy over the Taiwan's political status.

Third, cultural principles are being carried across regional and international organizations in China. These principles have been articulated in the context of significant Chinese participation in the International Society for Music Education, World Federation of International Music Competitions and other international music competitions. As described by Chu, Chinese culture is "an unascertained mixture of the old and new ... an ongoing social process" (5). Cultural differences in the Chinese state require the integration of diverse musical cultures and equality in a peaceful dialogue between traditions and cultures, as opposed to the "clash of civilizations" proposed by Samuel Huntington. We would argue that globalization, in the form of modernization, economic interdependence, and increased electronic communication, does not 
The Cultural Politics of Introducing Popular Music into China's Music Education

necessarily endanger local traditional values, and that nationalism and nation-building are among the most powerful forces in the modern world. Digital technology is required for introducing popular music, and to make education truly meaningful to Chinese youth (Shanghai Music Publisher for Grade 12 (second term) 58-65). The impact of technological developments such as CDs, film, multi-media computers, video and other audio-visual presentations, and the Musical Instruments Digital Interface (an internationally recognized means of transferring digital data) is profound in China's music education (Y. W. Jin 202-208; Law and Ho 507-8).

Nationalism, as defined in the Chinese education system, is compatible with the concept of globalism and the trend towards globalization. In order to encourage the teaching of cultural heritage and to strengthen cultural memory, many schools in China offer traditional Chinese music and calligraphy as extra-curricular activities. The promotion of traditional festivals, such as the Spring Festival (or Chinese Lunar New Year), the Dragon-boat Festival and the MidAutumn Festival is intended to cultivate the spirit, affections and feelings of the Chinese nation, and to create solidarity among the people of different ethnicities in the PRC (People's Daily News). In recent years, many Chinese scholars have strongly advocated the spirit of Chinese culture by urging Chinese people to read more classic Chinese literature (Zhang and Morrison 20). In a lesson on social responsibility in the community, Grade 9 students learn the about roles performers play in Beijing opera (a form of traditional Chinese theater dating back to the late $18^{\text {th }}$ century that combines music, vocal performance, dance, mine and acrobatics) (Shanghai Education Publisher for Grade 9 (second term) 54). As part of the same subject, the top ten Chinese popular celebrities from mainland China, Hong Kong and Taiwan are discussed, to teach students the different roles played and values displayed by their idols, who are celebrated 
The Cultural Politics of Introducing Popular Music into China's Music Education

for their courage and righteousness, their scientific attitude and spirit, and their nationalism (Shanghai Educational Publisher for Grade 9 (second term) 55-6).

Moreover, as most of Jay Chou's most popular songs are in the so-called "Chinese style" (Zhongguo feng, literally "China wind"), they are highly regarded in the Chinese music curriculum (Y. H. Wang 74). Chou has a great impact on young Chinese people's sense of being Chinese, due to his extensive use of traditional Chinese cultural symbols in his lyrics, some of which are adapted from ancient Chinese poems and literary classics. The idea of cultural China restores geographical determinism or the accommodation of China with a territorial mainland, with what Chun describes as a kind of "pan-national fundamentalism" (124). The lyrics of Chow's songs "Huo Yuan Jia", (the 2006 theme song for a Jet Li martial arts film) and "Dragon Fist", released in 2002, depict Chinese national pride and Chinese nationalism through the mastery of martial arts, enabling students to retain the distinctive spiritual essence of their national culture (Y. H. Wang 74). The lyrics of "Dragon Fist" read: "That Great Wall is like the dawning of a dream after five thousand years of silence. I use my arms to lift this whole land's weight...My right fist opens the heavens. Transform me into a dragon! ... The whole world is left with only one thought: waiting for a hero ... I am that dragon" (translated by the authors). The dragon, a major national symbol of China, is mentioned three times in the chorus: whilst the unity shown through phrases such as "the same skin, color and face" and "the same blood flows". Although most of his songs are composed in the rhythm and blues style, Chou always fuses traditional Chinese instruments and styles with his music. For example, his 2003 song, "The East Wind Breaks" ("Dong Feng Po" in Chinese), adopts a typical Chinese melody, but is composed in a rhythm and blues style. The song is distinctive for the effect of "a musician playing a Chinese pipa in a classic called 'Dong Feng Po' with a mild sense of melancholy", 
The Cultural Politics of Introducing Popular Music into China's Music Education

whilst Chou's rapping injects a sense of "modernity" (Fung, "The Emerging" 434). Recently, a monthly examination at a high school in Wuhan City required students to complete a line taken from Jay Chou's pop song, "Blue and White Porcelain" ${ }^{14}$; many people criticized the teacher who made up the examination paper, with some netizens suggesting that he might be a Jay Chou fan. The teacher denied this, stating that he used the pop song because his students like listening to pop music, and he wanted them to understand how classical Chinese ad been integrated into pop music (Education in Hebei). Chou's songs are popular in Chinese music curricula, as he breaks unwritten rules by combining tunes from different genres (e.g., rock, pop, classical symphonic, and rhythm and blues) from both Chinese and Western paradigms and integrates them with Chinese ethnic nationalism. Tu Wei-ming, an ethicist and a new Confucian, describes the space of "Chinese everywhere", the space of the Chinese diaspora, as "cultural China" (qtd. in Eperjesi 26). Such Taiwanese popular songs indicate a certain desirable past, and an imaginable cultural China.

To conclude, we can see that Chinese authorities are not just passively filtering the introduction of popular culture and music into school music curricula. Popular music materials still need to be fine-tuned, as state power is exercised to regulate political propaganda and censorship. Song lyrics have to convey positive attitudes on Chinese life and maintain the integrity of their Chinese identity, in order to meet political needs. Using popular music education to teach that traditional culture is the soul of Chinese society enables young people to understand contemporary ideological education more effectively.

\section{Conclusion and A Way Forward}


The Cultural Politics of Introducing Popular Music into China's Music Education

This paper has examined under-researched relationships between social transformation, popular music and education reform with special reference to China. It has explored how Chinese musicians, particularly Li Jinhui, and the Chinese government have valued the introduction of popular music in school education as a contribution to education reform within broader social contexts. Economic development tends to bring pervasive cultural changes, but the fact that mainland Chinese society has historically been shaped by both Confucianism and communism leaves a cultural heritage with enduring effects that influence subsequent developments in school music education. In much of China's recent history, liberalism and individualism have been under pressure from nationalism and socialism. Fukuyama and Mandelbaum argue that nationalism is declining and that the market will take over mighty nations, while Appadurai ("Disjuncture and Difference", Globalization) claims that the speed and ubiquity of global cultural flows have broken down national boundaries in unprecedented ways.

Popular music teaching can be non-confrontational for the Chinese state only if its materials are seen by the authorities to convey values education and patriotic messages. This paper has shown how the state has attempted to emphasize the cultivation of values education in order to counter individualism in school music education. It suggests that the promotion of nationalism through music education in China may be an effective means to consolidate state power. Teaching popular music in school involves praising China's national culture, particularly through song lyrics. When the Chinese government launched a campaign to assimilate popular music into school education, and music education in particular, what remained unchanged was the zeal with which the state strove to make popular music conform to its political ideology by integrating socialist and Confucian educational ideas. To some extent, the politics of introducing popular music to classrooms is a move to the center in Chinese nationalism, because it allows 
individuals to understand their own dreams and desires, and to modify dominant versions of nationalism.

This paper contributes to the on-going debate on the nature of teaching popular music in relation to Chinese nationalism. It has demonstrated how nationalism and values education are used to link together key areas of policy-making, including economic development, national unification and educational policy. Popular music has a growing presence in institutions of higher education in China, and the agenda for reforming the teaching profession has become more central since it has addressed the teaching and examining of popular music in teacher education (Cai; Liang; Song; W. H. Wu; Yang; Zhang). The introduction of nationalism and "collective values" has been and continues to be a strong focus in the China's school curriculum (Vickers 57). Besides values education, teaching popular music should also involve various forms of creating, arranging, and improvising music, so as to contribute to the viability of teaching strategies and their potential for music learning. In so doing, school children could have access, not only to political and ideological meanings, but also to the cultural diversity and musical meanings that popular music carries in the school curriculum. 
The Cultural Politics of Introducing Popular Music into China's Music Education

\begin{tabular}{|l|l|l|l|l|l|l|}
\hline & $\begin{array}{l}\text { Junior } \\
\text { middle } \\
\text { (first } \\
\text { year) }\end{array}$ & $\begin{array}{l}\text { Junior } \\
\text { middle } \\
\text { (second } \\
\text { year) }\end{array}$ & $\begin{array}{l}\text { Senior } \\
\text { middle } \\
\text { (first } \\
\text { year) }\end{array}$ & $\begin{array}{l}\text { Senior } \\
\text { middle } \\
\text { (second } \\
\text { year) }\end{array}$ & $\begin{array}{l}\text { College / } \\
\text { University } \\
\text { (first year) }\end{array}$ & $\begin{array}{l}\text { College / } \\
\text { University } \\
\text { (second } \\
\text { year) }\end{array}$ \\
\hline $\begin{array}{l}\text { Pop song stars, film/TV } \\
\text { stars }\end{array}$ & 49.2 & 44.9 & 31.3 & 38 & 18.7 & 26.5 \\
\hline Sports stars & 7.5 & 7.5 & 17.3 & 14.5 & 6.2 & 7.6 \\
\hline $\begin{array}{l}\text { Political and military } \\
\text { personalities }\end{array}$ & 10.5 & 8.3 & 14.2 & 14.9 & 31.2 & 33.2 \\
\hline $\begin{array}{l}\text { Scientists (technical } \\
\text { experts) }\end{array}$ & 8.9 & 8.7 & 5.9 & 6.5 & 7 & 5.7 \\
\hline $\begin{array}{l}\text { Literature and arts } \\
\text { persons/thinkers }\end{array}$ & 8.9 & 7 & 7.3 & 5.5 & 6.3 & 4.9 \\
\hline Heroic role models & 3.8 & 3.8 & 1.2 & 0.7 & 3.9 & 0.9 \\
\hline Entrepreneurs & 0 & 1 & 0.2 & 1.4 & 0.3 & 1.5 \\
\hline $\begin{array}{l}\text { Parents and family } \\
\text { members }\end{array}$ & 7 & 7.5 & 8.3 & 5.9 & 12 & 7.5 \\
\hline Teachers/Friends & 1.8 & 6 & 1.9 & 3.4 & 3.1 & 3.3 \\
\hline Fictional personages & 1.6 & 1.8 & 4 & 4.8 & 5.4 & 2.8 \\
\hline Self & 0.6 & 0.8 & 2.6 & 0.7 & 0.8 & 0.4 \\
\hline Others & 0.2 & 2.7 & 5.5 & 3.9 & 1.5 & 5.6 \\
\hline
\end{tabular}

Table 1 Categories of Idols Chosen by Students in Different School Years (\%) 


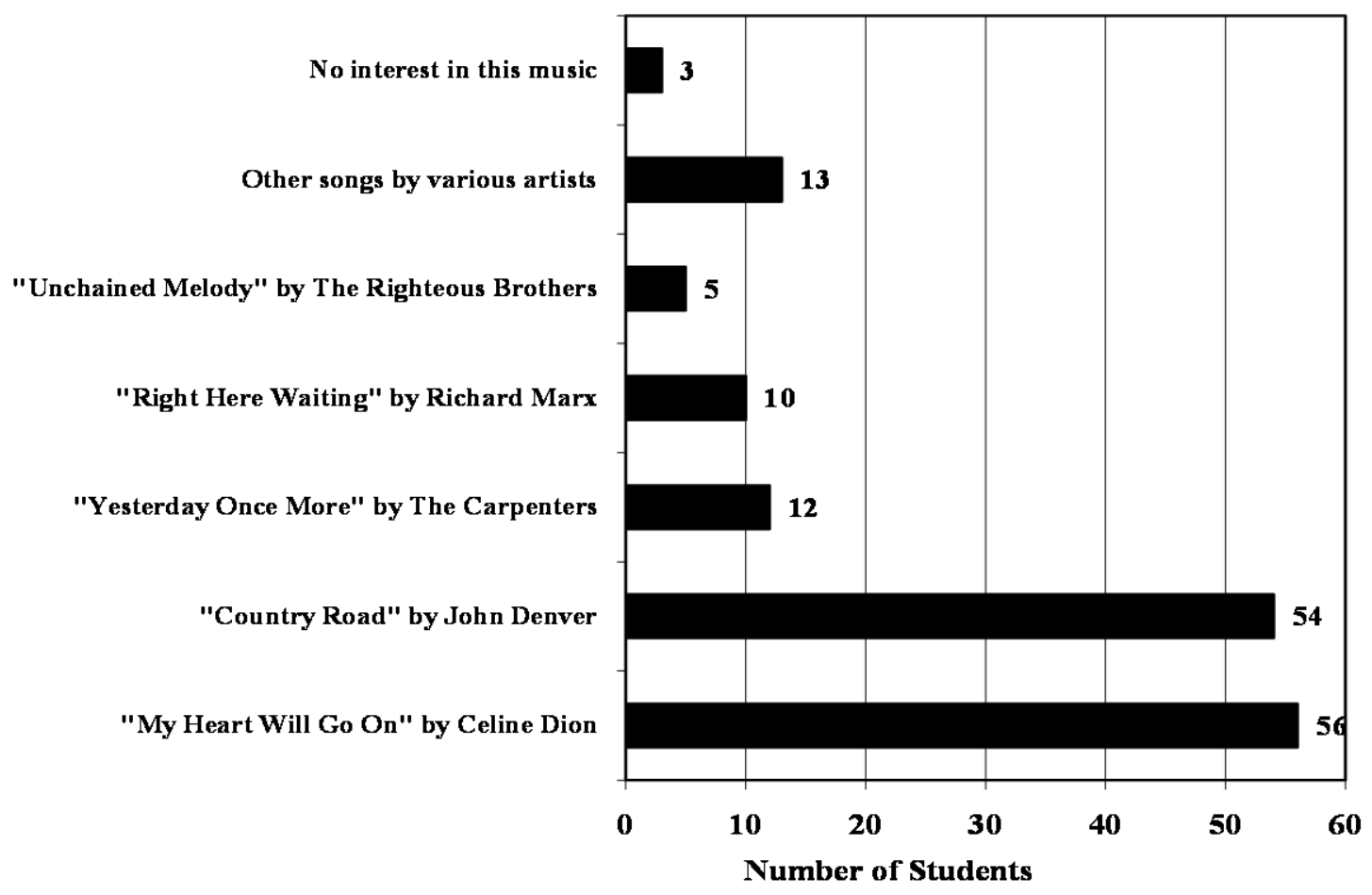

Figure 1 Favorite American Songs Preferred by Chinese College Students 


\section{Acknowledgement}

This research project was funded by a Faculty Research Grant from Hong Kong Baptist University. We would like to express our sincere gratitude to the editors and anonymous reviewers for their challenging and insightful comments and advice.

\section{Notes}

[1] The company left Shanghai in 1952 after the Chinese Communist Party (CCP) took over the mainland.

[2] The principal influence on Buck Clayton was Louis Armstrong (1901-1971). Clayton is credited for bridging the gap between traditional Chinese music and Mandarin pop. In 1934, the Clayton band performed at the palatial Canidrome Ballroom in Shanghai. It was one of the first bands to play in the Orient. Clayton left Shanghai before the outbreak of the Second Sino-Japanese War in 1937.

[3] Zhou Xuan first sang this song in 1937. It then became a number one hit in Japan, where it was translated and recorded by Watanabe Hamako (1910-1999) in 1940. In 1941, the song was recorded again, this time by the Japanese film star Yoshiko Yamaguchi (Shirley Yamaguchi), better known in China as Li Xianglan.

[4] Yan'an is one of the most famous cities in China's modern history and the history of Chinese Communist Party. It is located in the Shanbei region of Shaanxi province in China, about $350 \mathrm{~km}$ of Xian. Yan'an is famous for its cave dwellings, folk songs, drum art, paper-cut and many other folk crafts. 
The Cultural Politics of Introducing Popular Music into China's Music Education

[5] Lei Feng (1940-1962), a 22 year-old soldier who died in a tragic accident in 1963, was thought to exemplify the communist role model by doing good deeds or favors for people, and became a symbol of China's communist spirit.

[6] The eight revolutionary musicals were planned and promoted by Jiang Qing, the wife of Chairman Mao Zedong. The title "Shachiapang" was adopted for both the symphonic and opera works.

[7] Cui Jian, who established himself as China's first rock performer in the mid-1980s, is a most important figure who has confronted contradictions between the orientation of Chinese authorities and democratic convictions in China. Originally a trumpeter in the Beijing Philharmonic Orchestra (Beijing Jiaoxiang Yuetuan), in 1985, he formed his own band, Building Block, with six orchestral colleagues and recorded covers of Paul McCartney and Michael Jackson hits. In the late 1980s he performed the first Chinese rock song, "Nothing to My Name" (Yi Wu Suo You), described as the first time and electric guitar was used in performance in China. Following Cui, two bands, Hei Bao (Black Panther) and Tang Dynasty, became famous in the late 1980s and the early 1990s.

[8] Na Ying, an ethnic Manchu, is considered one of the most famous female singers in China. In 2010, she was named the mainland's most popular woman artist of the year for the sixth time.

[9] Liu Huan, a graduate with a major in French language, a university teacher and a famous pop singer and songwriter in China, performed the official Olympic theme song, "You and Me”, with British singer Sarah Brightman at the Olympic Games Opening Ceremony in Beijing on 8 August, 2008. 
The Cultural Politics of Introducing Popular Music into China's Music Education

[10] In 2004, 2006, 2007 and 2008, Jay Chou was named the Best-Selling Artist in China by World Music Awards, for his albums Common Jasmine Orange, Still Fantasy and On the Run. Chou's internet-based fan club is one of the biggest Chinese networks visited by Chinese youths (Fung Fandom).

[11] Astro Boy is a Japanese manga series first published in 1952, and first broadcast in Japan in 1963. The story is about a young robot named Astro Boy, created by a brilliant scientist named Dr. Tenma, and his incredible powers. China's Film Bureau, regulates foreign films seeking distribution in China, awarded Astro Boy co-production status in 2009. Astro Boy (2009) was an American, Japanese and Chinese co-production, but was not successful at the box office in the former two countries, despite setting box-office records for a computer-animated 3-D film in China.

[12] Yu Dan, a famous media expert and professor at Beijing Normal University, attracted national attention with her televized lecture series on the Analects of Confucius, written by his disciples around $475 \mathrm{BC}$, at China Central Television in 2006. The transcript, edited into a book titled Yu Dan's Notes on the Analects, sold 10,000 copies on the first day of release. The English edition of her work Confucius from the Heart: Ancient Wisdom for Today's World (translated by Esther Tyldesley and published by Pan Macmillan in collaboration with Zhonghua Book Company) was released in 2009.

[13] In the last decade, Beijing officials have banned only those Taiwanese singers who performed at the inauguration of President Chen Shui-bian, a fierce advocate of Taiwanese independence. Taiwan's top pop singer, Chang Hui Mei, performed Taiwan's national anthem at Chen Shui-bian's May, 2000 inauguration ceremony, and was consequently banned from performing or selling records in China, and from advertising in the Chinese 
The Cultural Politics of Introducing Popular Music into China's Music Education

media. China also stripped Taiwanese rock singer Wu Bai of his title of "Best Taiwanese Male Singer" in retaliation for his singing at the inauguration party.

[14] Blue and white porcelain (literally "blue flowers") is thought to have originated in China in the North Song dynasty (960-1127). It was perhaps at its most impressive in the second half of the $14^{\text {th }}$ and early $15^{\text {th }}$ century. The term designates white pottery and porcelain decorated under the glaze with a blue pigment; the decoration is commonly applied by hand, stenciling, or transfer-printing.

\section{Works Cited}

Appadurai, Arjun. "Disjuncture and Difference in the Global Cultural Economy." Public Culture 2 (1990): 1-24. Print.

. Modernity at Large: Cultural Dimension of Globalisation. Minneapolis, Minn.: University of Minnesota Press, 1996. Print. . Globalization. Durham, NC: Duke University Press, 2001. Print.

Arts Faculty Teaching Materials Editing Group, Beijing Physical Education University. Yinyue Zhishi Yи Tiyue Yinyue (Music Knowledge and Physical Education Music). Beijing: Beijing Physical Education University Press, 2005. Print.

Baranovitch, Nimrod. China's New Voices: Popular Music, Ethnicity, Gender, and Politics, 1978-1997. Berkeley and Los Angeles, CA: University of California Press, 2003. Print.

Bauman, Zygmunt. Globalization: The Human Consequences. New York: Columbia University Press, 1998. Print.

Beck, Ulrich. "The Cosmopolitan Society \& Its Enemies." Theory, Culture \& Society 19.1-2 (2002): 17-44. Print. 
The Cultural Politics of Introducing Popular Music into China's Music Education

Beijing Review. "Shall the Chinese Worry about Japanese and South Korean Pop Culture?." 48 (27 July 2005). Web. 29 October 2010 <http://www.bjreview.com.cn/En-2005/05-27e/zm-1.htm>.

Bell, Daniel. The Coming of Post-Indus-trial Society. New York: Basic Books, 1973. Print. . The Cultural Contradictions of Capitalism. New York: Basic Books, 1976. Print.

Bhagwati, Jagdish. "Coping with Antiglobalization: A Trilogy of Discontents." Foreign Affairs, 81 (January/February 2002): 2-7. Print.

Brace, Tim. "Popular Music in Contemporary Beijing" Modernism and Cultural Identity." Asian Music XXII.2 (1991): 43-66. Print.

Brown, Veda. "Growing the influence of Hip-Hop Music on Middle-School Students' Feelings, Thinking, and Behaving.” Negro Education Review 57.1/2 (2006): 49-68. Print.

Bryant, Lei Outyang. "Flowers on the Battlefield Are More Fragrant." Asian Music 38 (Winter/Spring 2007): 88-122. Print.

Cai, Dan-dan. "Discussion on How Popular Music to Be Entered Classrooms." Yishu Jiaoyu 3 (2009): 53-4. Print.

Cao, Li. Putong Xuexiao: Yinyue Jiaoyue Xue (General Schools: Methods of Music Education). Shanghai: Shanghai Educational Press, 1996. Print.

Cathcart, Adam. "Japanese Devils and American Wolves: Chinese Communist Songs from the War of Liberation and the Korean War.” Popular Music and Society 33.2 (2010): 203-218. Print.

Castles, Stephen and Davidson, Alastair. Citizenship and Migration: Globalization and the Politics of Belonging. New York: Routledge, 2000. Print. 
Chen, Szu-wei. "The Rise and Generic Features of Shanghai Popular Songs in the 1930s and 1940s.” Popular Music 24.1 (2005): 107-125. Print.

Chen, Yan-ru. "A Survey on the Situation of Pop Music in Quality Education at General College and Its Tactics.” Journal of Sichuan Vocational and Technical College 19.4 (2009): 63-65. Print.

Cheung, Kwok Wah and Pan Suyan. "Transition of Moral Education in China: Towards Regulated Individualism.” Citizenship Teaching and Learning 2.2 (2006): 37-50. Web. 6 November 2010.

Chinese Internet Network Information Center. $24^{\text {th }}$ Statistical Report on Internet Development in China (July 2009). $\quad$ Web. $\quad 9 \quad$ November 2010. <http://www.cnnic.net.cn/html/Dir/2009/07/28/5644.htm>

China, Ou. “China’s National Identity during Hu Jintao's Age.” Asian Social Science 6.9 (2010): 147-151. Print.

Chong, Woei-lien. "Young China's Voice of the 1980s: Rock Star Cui Jian." China Information 6.1 (Summer 1991): 55-74. Print.

Chow, Gregory C. "Globalization and China's Economic Development." Pacific Economic Review 11.3 (2006): 271-285. Print.

Chu, Godwin, C. "Popular Media: A Glimpse of the New Chinese Culture." Popular Media in China: Shaping New Cultural Patterns. Ed. Godwin C. Chu. Honolulu: Hawaii, 1978. 1-15. Chun, Allen. "Fuck Chineseness: On the Ambiguities of Identity as Ethnicity as Culture." Boundary 2: an international journal of literature and culture 23(2) (1996): 111-38.

Cloonan, Martin. "What is Popular Music Studies? Some Observations." British Journal of Music Education 22.1 (2005): 77-93. Print. 
De Kloet, Jeroen. "Popular Music and Youth in Urban China: The Dakou Generation." China Quarterly 183 (2005): 609-626. Print. . "Sonic Sturdiness: The Globalization of "Chinese" Rock and Pop". Critical Studies in Media Communication 22.4 (2005): 321-338. Print.

Ding, Sheng and Saunders, Robert A. "Talking up China: An Analysis of China's Rising Cultural Power and Global Promotion of the Chinese Language." East Asia: An International Quarterly 23.2 (2006): 3-33. Print.

Dunbar-Hall, Peter. Teaching Popular Music. Sydney: Science Press, 1993. Print. "Designing a Teaching Model for Popular Music." Teaching Music. Ed. Gary Spruce. London: Open University Press, 1996, 216-226. Print.

Dunbar-Hall, Peter and Wemyss, Kathryn. "The Effects of the Study of Popular Music on Music Education”. International Journal of Music Education 36.1 (2000): 23-34. Print.

Duncan-Andrade, Jeffrey M.R. "Your Best Friend or Your Worst Enemy: Youth Popular Culture, Pedagogy, and Curriculum in Urban Classrooms." The Review of Education 26.4 (2004): 313-337. Print.

Education in Hebei. "Jay Chow's Song Appears in a Monthly Exam for High School Students." $\begin{array}{lllll}\text { (11 November } & \text { 2010). } & \text { Web. } & 18 & \text { November }\end{array}$ <http://english.hebei.com.cn/edu/learn/20101111/4265.html>.

Eperjesi, John R. "Crouching Tiger, Hidden Dragon: Kung Fu Diplomacy and the Dream of Cultural China.” Asian Studies Review 28 (2004): 25-39. Print.

Evelein, Frits. "Pop and World Music in Dutch Music Education: Two Cases of Authentic Learning in Music Teacher Education and Secondary Music Education.” International Journal of Music Education 24.2 (2006): 178-187. Print. 
Fain, Jr., Thomas A. "American Popular Culture Should We Integrate it into American Education?.” Education 124 (2004): 590-594. Print.

Fairbrother, Gregory P. "Patriotic Education in a Chinese Middle School." Citizenship Education in Asia and the Pacific Concepts and Issues. Ed. Wing On Lee, David L. Grossman, Kerry J. Kennedy and Gregory P. Fairbrother. Hong Kong: Comparative Education Research Centre, the University of Hong Kong, 2004, 157-174. Print.

Fan, Lei. "Education Reform and Creation in the Elective Music Study in High Schools." Science \& Technology Information 5 (2010): 523. Print.

Field, Andrew David. Shanghai's Dancing World: Cabaret Culture and Urban Politics, 1919 1954. Hong Kong: The Chinese University Press, 2010. Print.

Fukuyama, Francis. The End of History and the Last Man. New York: Free Press, 1992. Print.

Fung, Anthony Y. H. "The Emerging (National) Popular Music Culture in China." Inter-Asia Cultural Studies 8.3 (2007): 425-437. Print.

. "Fandom, Youth and Consumption in China." European Journal of Cultural Studies 12.3 (2009): 285-303. Print.

Garrett, V. M. Heaven is High, The Emperor Far Away. Oxford: Oxford University Press, 2002.

Gass, Glenn. "Why Don't We Do It in the Classroom?," South Atlantic Quarterly 90.4 (1991): 729-736. Print.

Giddens, Anthony. Runaway World: How Globalization is Reshaping Our Lives. New York: Routledge, 2000. Print.

Gill, Bates and Huang, Yanzhong. "Sources and Limits of Chinese 'Soft Power'." Survival 48.2 (Summer 2006): 17-36. 
Green, Lucy. "Research in the Sociology of Music Education: Some Fundamental Concepts." Music Education Research 1.2 (1999): 159-169. Print.

. How Popular Musicians Learn: A Way Ahead for Music Education. Aldershot, UK: Ashgate Publishing Ltd, 2001. Print.

. "Popular Music Education in and for Itself, and for 'Other' Music: Current

Research in the Classroom.” International Journal of Music Education 24.1 (2006): 101118. Print.

Guo, Sheng-jian. Yinle Xiaoyue Lun (Theory of Music Education) (2nd edition). Hunan: Hunan Wenyyi Chubanshe, 2006. Print.

Hall, Stuart. "Race, Culture, and Communications: Looking Backward and Forward at Cultural Studies.” Rethinking Marxism 5.1 (1992): 10-18. Print.

He, Xiaozhong. "Survey Report on Idol Worship among Children and Young People." Chinese Education and Society 39.1 (2006): 84-103. Print.

Helig, Charles C., Arnold, Mary Louise, Tan, Dingliang, and Boyd, Dwight. "Chinese Adolescents' Reasoning about Democratic and Authority-based Decision Making in Peer, Family, and School Context." Child Development 74 (2003): 783-800.

Ho, Wai-Chung. "Westernization and Social Transformations in Chinese Music Education, 1895-1949." History of Education 32.3 (May 2003): 289-301. . "Social Change and Nationalism in China's Popular Songs." Social History 31.4 (2006): 435-453. Print. "Popular Culture in Mainland Chinese Education." International Education Journal 7.3 (2006): 348-363. Print. 

. "Dynamics of Social Change and School Music Education in Shanghai."

Education and Society 24.1 (2006): 77-95. Print.

. "Moral Education in China's Music Education: Development and

Challenges." International Journal of Music Education 28.1 (2010): 71-87. Print.

. "China: Socio-political Constructions of School Music." The Origins and

Foundations of Music Education: Cross-cultural Historical Studies of Music in

Compulsory Schooling. Ed. Gordon Cox and Robin Stevens. London and New York:

Continuum, 2010, 189-204. Print.

Ho, Wai-Chung and Law, Wing-Wah. "Values, Music and Education in China." Music Education Research 6.2 (2004): 149-167. Print.

. "Challenges to Globalisation, Localisation, and

Sinophilia in Music Education: A Comparative Study of Hong Kong, Shanghai, and Taipei." British Journal of Music Education 23.2 (2006): 217-237. Print.

Hsü, Immanuel C.Y. The Rise of Modern China. $3^{\text {rd }}$ ed. New York: Oxford University Press, 1990. Hung, Chang-tai. "The Politics of Songs: Myths and Symbols in the Chinese Communist War Music, 1937-1949.” Modern Asian Studies 30.4 (October 1996): 901-929. Print. Huang, Qi-Zhi. The Age of Shanghaiese Pops. Hong Kong: Joint Publishing, 2001. Print. Huntington, Samuel P. "The Clash of Civilizations?.” Foreign Affairs 72.2 (1993): 22-49. Print. International Market News. "Animation and Comics Evolve into a Serious China Industry." 21

November 2006. Web. 23 May 2010. 〈http://info.hktdc.com/imn/06112103/toys097.htm〉. Jenkins, Henry. Convergence Culture: Where Old and New Media Collide, New York and London: New York University Press, 2006. Print. 
Jian, Miaoju and Liu, Chang-de. “'Democratic-entertainment' Commodity and Unpaid Labor or Reality TV: A Preliminary Analysis of China's Supergirl.” Inter-Asia Cultural Series 10. 4 (2009): 524-543. Print.

Jin, Ye-wen. Chuzhong Yinyue Xin Kecheng Jiaoxuefa (Early Secondary School New Music Curriculum Teaching Methods). Beijing: Higher Education Publisher, 2003. Print.

Jin, Ying-zhe. "Reflections on Pop Music Courses for College Students." Journal of North China Institute of Aerospace Engineering 19.6 (2009): 51-53. Print.

Jones, Andrew F. 'The Politics of Popular Music in post-Tiananmen China." Popular Protest and Political Culture in Modern China. Ed. Jeffrey N. Wasserstrom and Elizabeth J. Perry. Boulder, CO: Westview Press, 1994, 148-65. Print. . Yellow Music: Media Culture and Colonial Modernity in the Chinese Jazz Age. Durham and London: Duke University Press, 2001. Print.

Kiely, Ray. "The Changing Face of Anti-globalization Politics: Two (and a half) Tales of Globalization and Anti-globalization.” International Affairs 2.1 (2005): 134-150. Print.

Kim, Sujeong. "Interpreting Transnational Cultural Practices." Cultural Studies 23.5/6 (2009): 736-55. Print.

Kraus, Richard C. Pianos and Politics in China: Middle-Class Ambitions and the Struggle over Western Music. New York: Oxford University Press, 1989.

Kwok, Theodore Jen. Zheng: A Chinese Zither and Its Music, Michigan: University Microfilms International, 1987. Print.

Kraus, Richard Curt. Pianos and Politics in China: Middle-Class Ambitions and the Struggle over Western Music. New York: Oxford University Press, 1989. Print. 
Landsberger, Stefan. R. "Learning by What Example? Educational Propaganda in Twenty-firstCentury China”. Critical Asian Studies 33. 4 (2001): 541-571. Print.

Law, Wing-Wah "Citizenship, Citizenship Education, and the State in China in a Global Age." Cambridge Journal of Education 36.4 (2006): 597-628. Print.

Law, Wing-Wah and Ho, Wai-Chung. "A Review of Values Education in China's School Music Education: from Nationalism to Globalisation." Journal of Curriculum Studies 41.4 (2009): 501-520. Print.

Lebler, Don. "Popular Music Pedagogy: Peer Learning in Practice." Music Education Research 10.2 (2008): 193-213. Print.

Lee, Gregory B. "The "East Is Red" Goes Pop: Commodification, Hybridity, and Nationalism in Chinese Popular Songs and Its Televisual Performance.” Popular Music 14.1 (1995): 95110. Print. . Troubadours, Trumpeters, Troubled Makers: Lyricism, Nationalism, and Hybridity in China and Its Others. London: Hurst \& Co., 1996. Print.

Lee, Wing On, and Ho, Chi Hang. "Ideopolitical Shifts and Changes in Moral Education in China.” Journal of Moral Education 34.4 (2005): 413-31. Print.

Liang, Jin. “Pop Music Entering into College Classroom.” Journal of Huaihua University 28.3 (2009): 78-80. Print.

Lieber, Robert J. and Weisberg Ruth E. "Globalization, Culture, and Identities in Crisis." International Journal of Politics, Culture \& Society 16.2 (2006): 273-296. Print.

Lin, Hai-xia. "The Practice of Teaching Popular Music in Secondary School.” Time Education 4 (2010): 171. Print.

Lowe, Geoffrey. The Rock Book. Sydney: McGraw-Hill, 1997. Print. 
Lu, Li. "Some Reflections on the Introduction of Pop Music to Music Classrooms in Secondary Schools." Journal of Shangrao Normal University 29.1(2010): 117-120. Print.

Lully, James. China Turned On: Television, Reform, and Resistance. London and New York: Routledge, 1991.

Maliangkay, Roald. “Keep Your Enemies Closer: Protecting Korea's Pop Culture in China”. Korean Histories 2.1 (2010): 34-44. Web. 9 November 2010 $<$ http://www.koreanhistories.org/files/Volume_2_1/KH_2_1\%20MaliangkayKeep\%20Your\%20Enemies\%20Closer.pdf>.

Mandelbaum, Michael. The Ideas That Conquered the World: Peace, Democracy, and Free Markets in the Twenty-First Century. New York: Public Affairs, 2002. Print.

Marx, Karl. Foundations of the Critique of Political Economy. New York: Vintage Books, 1973. Print.

Matusitz, Jonathan. "Semiotics of Music: Analysis of Cui Jian's "Nothing to My Name," the Anthem for the Chinese Youths in the post-cultural Revolution Era". Journal of Popular Culture 43.1 (2010): 156-175. Print.

Micic, Peter. A Summary of the Cultural Mapping Reports: Beijing, Shanghai and Guangzhou (A Report of the Embassy of the Kingdom of the Netherlands to China). (September 2009). Web. 9 November 2010 <http://www.artsfoundation.nl/archive/091105_Update_theater_dansbeeldendekunst_sept2 009.pdf>

Middleton, Richard. Studying Popular Music. Ballmoor (UK): Open University Press, 1990. Print. 
The Cultural Politics of Introducing Popular Music into China's Music Education

Ministry of Education, the People's Republic of China. Quanri zhi yiwu jiaoyu:Yinyue kecheng biaozhun (Shiyan gao) [Full-day voluntary education: Standard of music curriculum (experimental version)] . Beijing: Beijing Normal University Publishing Company, 2001. Print.

Mittler, Barbara. "Popular Propaganda? Art and Culture in Revolutionary China." Proceedings of the American Philosophical Society 152.4 (December 2008): 466-89. Print. . "Eight Stage Works for 800 Million People." The Opera Quarterly 26.2-3 (Spring-Summer 2010): 377-401. Print.

Newsom, Daniel. “Rock's Quarrel with Tradition: Popular Music's Carnival Comes to the Classroom.” Popular Music and Society 22.3 (1998): 1-20. Print.

Ng,Wai-ming. "The Impact of Japanese Comics and Animation in Asia." Journal of Japanese Trade \& Industry (July/August 2002): 1-4. Web. 18 November 2010 <http://www.cuhk.edu.hk/jas/staff/benng/publications/anime1.pdf>

Nyíri, Pál. "From Starbucks to Carrefour: Consumer Boycotts, Nationalism and Taste in Contemporary China.” PORTAL Journal of Multidisciplinary International Studies 6.2 (2009): 1-25. Print.

Ogawa, Masashi. "Japanese Popular Music in Hong Kong: What Does TK Present?". Refashioning Pop Music in Asia. Eds. Allen Chun, Ned Rossiter, and Brian Shoesmith. London and New York: RoutledgeCurzon, 2004. Print.

Pease, Rowan. "Internet, Fandom, and K-wave in China". Korean Pop Music: Riding the Wave. Ed. Keith Howard. Folkestone, Kent: Global Oriental, 2006, pp. 176-89. 
People's Daily News. "China to Revive Traditional Festivals to Boost Traditional Culture." 25

June 2005. Web. 31 May 2010.

<http://english.people.com.cn/200506/25/eng20050625_192259.html>.

People's Music Publisher. Yinyue (Music) (Grade 1, Second Term). Heilongjiang: People's Music Publisher, 2005. Print.

. Yinyue (Music) (Grade 2, Second Term). Heilongjiang: People's

Music Publisher, 2005. Print.

. Yinyue (Music) (Grade 3, Second Term). Heilongjiang: People's

Music Publisher, 2005. Print.

. Yinyue (Music) (Grade 4, Second Term). Heilongjiang: People's

Music Publisher, 2006. Print.

. Yinyue (Music) (Grade 8, Second Term). Heilongjiang: People's

Music Publisher, 2007. Print.

Perris, Arnold. "Music as Propaganda: Art at the Command of Doctrine in the People's Republic's of China”. Ethnomusicology 27.1 (1983): 1-28. Print.

Pop Music Conservatory, Sichuan Conservatory of Music. "Pop Singing Department". Web. 8 November $2010<$ http://www.popmc.net/eng/index.php/academy/index/6>.

Robins, Kevin, and Webster, Frank. Times of the Technoculture: from the Information Society to the Virtual Life. New York: Routledge, 1999. Print.

Rupke, Heidi Netz and Blank, Grant. "Country Roads" to Globalization: Sociological Models for Understanding American Popular Music in China.” Journal of Popular Culture 42.1 (2009): 126-146. Print. 
The Cultural Politics of Introducing Popular Music into China's Music Education

Schell, Orville. Mandate of Heaven: a New Generation of Entrepreneurs, Dissidents, Bohemians and Technocrats Lays Claim to China's Future. New York: Simon \& Schuster, 1994. Print.

Scott, A. C. Literature \& the Arts in Twentieth Century China. Garden City, N.Y.: Doubleday, 1963. Print.

Seifried, Scott. "Exploring the Outcomes of Rock and Popular Music Instruction in High School Guitar Class: A Case Study.” International Journal of Music Education 24.2 (2006): 168177. Print.

Shah, Shahanum Mohamad. "Popular Music in Malaysia: Education from the Outside." International Journal of Music Education 24.2 (2006): 132-139. Print.

Singer, Peter. One World: The Ethics of Globalization. New Haven: Yale University Press, 2002. Shanghai Educational Publisher. Shehui (Society) (Grade 9, Second Term). Shanghai: Shanghai Educational Publisher, 2005. Print.

Shanghai Music Publisher. Yishu (Arts) (Grade 12, First Term). Shanghai: Shanghai Music Publisher, 2004. Print. . Yishu (Arts) (Grade 12, Second Term). Shanghai: Shanghai Music Publisher, 2004. Print. Yishu (Arts) (Grade 13, First Term). Shanghai: Shanghai Music Publisher, 2004. Print. . Yishu (Arts) (Grade 13, Second Term). Shanghai: Shanghai Music Publisher, 2005. Print.

Shaonian Ertong Chubian She. Yueyin (Music) (Grade 7, First Term). Shanghai: Shanghai Xinhua Chubian She, 2004. Print. 
Shaonian Ertong Chubian She. Yueyin (Music) (Grade 7, Second Term). Shanghai: Shanghai Xinhua Chubian She, 2004. Print.

Song, Jie. "How Does a Music Teacher Face with the Education of the New Century." Journal of Xichang College (Natural Science Edition) 21.2 ( 2007): 101-3 \& 110. Print.

Southcott, Jane E. and Lee, Angela Hao-chun. "Missionaries and Tonic Sol-fa Music Pedagogy in $19^{\text {th }}$-century China." International Journal of Music Education 26.3 (2008): 213-228. Print.

Spence, Jonathan. Mao Zedong. New York: Viking, 1999. Print.

Steen, Andreas 'Tradition, Politics and Meaning in $20^{\text {th }}$ Century China's Popular Music - Zhou Xuan: "When Will the Gentleman Come Back Again?." Chime 14-15 (1999/2000): 124153. Print.

Stevens, Robin S. "Tonic Sol-fa in Asia-Pacific Countries - The Missionary Legacy". AsiaPacific Journal for Arts Education 5.1 (2007): 52-76. Print.

Suárez-Orozco, M.M., and Qin-Hilliard, D.B. ed. Globalization: Culture and Education in the New Millennium. Berkeley, CA: University of California Press, 2004. Print.

Swanwick, Keith. Popular Music and the Teacher. Oxford: Pergamon Press, 1968. Print.

Synovate, The. "Global Survey Reveals Music Trends Rocking Fans Across the World." 28 $\begin{array}{lllll}\text { January } & 2010 . & \text { Web. } & 18 & \text { October }\end{array}$ <http://www.synovate.com/news/article/2010/01/global-survey-reveals-music-trendsrocking-fans-across-the-world.html>.

Telecom Asia Staff. "China Rocks the West in Mobile Music: Survey.” 12 February 2008. Web. 18 October $2010<$ http://www.telecomseurope.net/content/china-rocks-west-mobile-musicsurvey> 
Tian, Xiao-hong, and Du, Xue-yuan. "On the Music Educational Thought of Confucius." Jishujiaiyu (Arts Education) 4 (2008): 60-2. Print.

Tomlinson, John. Globalization and Culture. Oxford: Polity Press, 1999. Print.

Valenzuela, Angela. Subtractive Schooling: U.S. Mexican Youth and the Politics of Caring. Albany: State University of New York Press, 1999. Print.

Vickers, Edward. "The Opportunity of China? Education, Patriotic Values and the Chinese State". Education as a Political Tool in Asia. Ed. Marie Lall and Edward Vickers. London and New York: Routledge. Print.

Vulliamy, Graham and Lee, Edward. eds. Pop Music in School. Cambridge: Cambridge University Press, 1980. Print.

Wang, Feng-yan. "Confucian Thinking in Traditional Moral Education: Key Ideas and Fundamental Features." Journal of Moral Education 33.4 (2004): 429-447. Print.

Wang, Yong-hui. “To Compose Pop Music by Means of Traditional Culture." Explorations in Music (Yinyue Tansuo), 1 (2010): 74-6. Print.

White, Cameron, and Mccormack, Susan. "The Message in the Music: Popular Culture and Teaching in Social Studies.” The Social Studies (2006, May/June): 122-127. Print.

Winter, Neal "The Learning of Popular Music: A Pedagogical Model for Music Educators." International Journal of Music Education 22.3 (2004): 237-247. Print.

Wong, Isabel K.F. “China”. Excursions in World Music. Ed. Bruno Nettl, Charles Capwell, Philip V. Bohlman, Isabel K.F. Wong and Thomas Turino. New Jersey: Prentice Hall, 1992. 70-104. Print. 
The Cultural Politics of Introducing Popular Music into China's Music Education

Wu, Wen-han. "Research into the Impact of Pop Music on Constructing Harmonious Campus". Journal of Henan University of Technology (Social Science) 5.2 (2009): 154-6 and 168. Print.

Wu, Zhi-xian. "Features and Function of Higher School Music Teaching in Moral Education." Journal of Yancheng Institute of Technology (Social Science Edition) 22.1 (2009): 92-4. Print.

Xu, Youwei. "Confucius - An Educationalist of Aesthetics in Ancient China." Journal of Popular Culture 27.2 (1993): 121-128. Print.

Xiong, Yuan-bin and Li, Sheng. "Effect of South Korean Pop Culture on the Potential Tourists for Chinese Mainland". Chinese Business Review 6.2 (2007): 20-26. Print.

Yan, Xuetong. "The Rise of China in Chinese Eyes." Journal of Contemporary China 10.26 (2001): 33-39. Print.

Yang, Li. "Discussion on How Popular Music could Enter into Music Appreciation Lessons". Heilongjiang Science and Technology Information 15 (2009): 167. Print.

Yeh, Yueh-yu "Historiography and Sinification: Music in Chinese Cinema of the 1930s." Cinema Journal 41.3 (2002): 78-97. Print.

Yu, Jing. "A Thought on the Introduction of Popular Songs into School Music Lessons." Yellow River of The Song (September 2009): 44-45. Print.

Yu, Tianlong. "The Revival of Confucianism in Chinese Schools: A Historical-political Review." Asia Pacific Journal of Education 28.2 (2008): 113-129. Print.

Zhang, Cheoyi, and Morrison, Johnetta W. "Imparting Cultural Values to Chinese Children Through Literature". International Journal of Early Childhood 42.1 (2010): 7-26. Print.

Zhang, Rui "A Light Talk on Function of Teacher Training in Higher Music Education in the Introduction of Popular Music.” Time Education 2009: 11-12, 87. Print. 
Zou, Hulin. "Patriotic Songs Sing More Individualist Tune." China Daily 17 March 2005. Web.

8 November 2010

< http://www.chinadaily.com.cn/english/doc/2005-03/17/content_425967.htm> 